that everything takes longer than I thought it would-especially the mail service. I have had to use telefax on a few occasions when "we simply must have it by Friday." Be sure to allow yourself plenty of time. My exchange took longer to arrange than most I know of, but much of that time was spent finding an exchange partner.

Another thing I learned was that in your initial inquiry, make your institution and area as attractive as possible. I doubt that too many people in Ireland are all that familiar with Vermont. After I described the city and noted that it was located 90 minutes from Montreal and 4 hours from Boston, the area seemed much more attractive. After my initial letter received so few responses, I jazzed it up so that I emphasized the city and area more. I know this made a vast difference.

It has now been two years since I first started to think about the possibility of an exchange. It was hard to believe it until I actually was sitting at my desk at Trinity College. Since most of my time had been taken up with what Brid would encounter when she arrived in Vermont, I really hadn't any time to worry or wonder about what awaited me in Dublin. I'm sure when I return next Fall, all the time, frustrations, and worries of the past two years will be just a memory and it will have all been worthwhile.

\title{
Newberry Library and Center for Research Libraries announce cooperative plan
}

The Newberry Library, Chicago's pre-eminent humanities research library, and the Center for $\mathrm{Re}$ search Libraries (CRL) have agreed to inaugurate a program of inter-institutional cooperation. The program stresses improved access to each other's collections as well as joint projects in preservation and collection development.

Newberry Library fellows may now use CRL's unrestricted collections on site at the Newberry or through interlibrary loan. The Newberry in turn is offering to CRL member institutions, via interlibrary loan, materials from its collection of American Indian studies on microform. Newberry Library collections have traditionally not been available for loaning to other libraries.

The two institutions are planning cooperative collection development to extend their resources. Mutually beneficial collaboration in preservation and conservation will blend the extensive experience of CRL in preservation microfilming with the significant expertise in conservation and restoration practices of the Newberry staff, which has been a leader in this field.

A joint working group has been established to recommend procedures for implementing all areas of cooperation.

The Newberry Library, which celebrates its 100th birthday this fall, houses collections in history and the humanities from the Middle Ages to the 20th century. The Newberry awards some $\$ 300,000$ annually in fellowships for research in residence, sponsors four centers for scholarly research, and conducts numerous outreach programs to draw public attention to its collections.

The Center for Research Libraries was founded in 1949 to provide a means by which the libraries of major research institutions can practice cooperative collection development and management. The Center's prinicipal program is the acquisition and preservation of a dedicated-to-lending collection, now exceeding 3.6 million volumes and 1.2 million microfilm units, that complements and supplements the collections of its 150 member institutions.

\section{ACRL executive summary}

Every month, JoAn Segal, ACRL's executive director, will summarize Association activity. The " $E x$ ecutive Summary" will highlight accomplishments of broad interest to the Association.

Although the New Orleans Conference seems a long way off, Sandy Donnelly has been soliciting new course proposals, advertising scholarships and cooperative courses, and developing new courses on "Negotiating Contracts with Vendors" and "In- formation Liability," based on last spring's needs assessment.

ACRL President Joanne Euster appointed a new Task Force on Awards to review ACRL's awards program and make recommendations-Joan Chambers chairs the task force.

Mary Ellen Davis is working with the ACRL Performance Measures chair Virginia Tiefel to revise and circulate an RFP seeking an author for a Manual of Output Measures for Academic Li- 
braries. An author will be selected at Midwinter.

Plans were finalized for the October 18-20 meeting in Atlanta to plan a project that would allow ACRL to help libraries in Historically Black Colleges and Universities (HBCU's).

ALA released 1987 year-end figures showing that ACRL exceeded 10,000 members as of August 31, 1987.

Equipment was received in our Middletown, Connecticut, office for automating the production of Choice magazine through the $\mathrm{H}$. W. Wilson Company.

ACRL staff members began training for their newly-established Quality Circle.

Joseph Boisse met with ACRL staff and attended the ALA Division Leadership Program for all division presidents-elect. As a result, one program in Dallas will be co-sponsored by ALA president Bill Summers and all the ALA divisions. The topic will be “Access to Information.”-JoAn S. Segal.

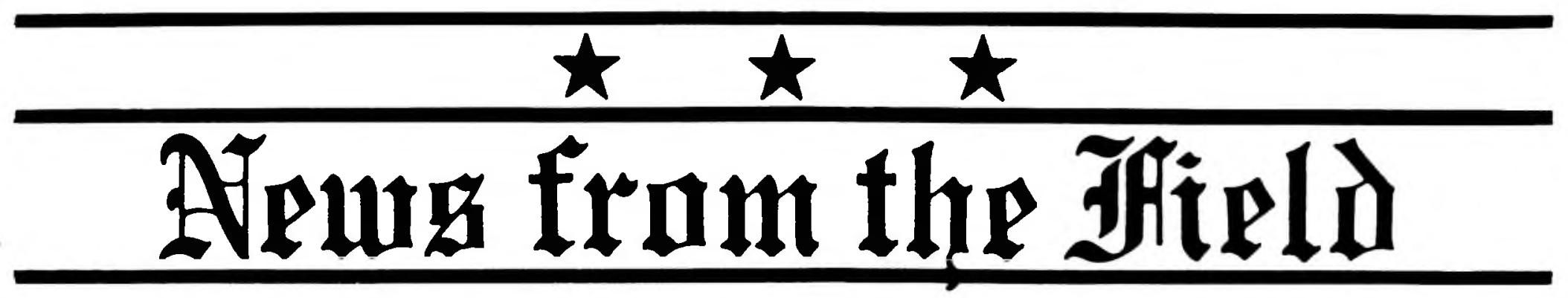

\section{Acquisitions}

- The Library of Congress, Washington, D.C., will acquire the personal papers of internationally known businessman, philanthropist and citizen diplomat Armand Hammer (b. 1898), chairman of the board of Occidental Petroleum Corporation. The Hammer collection will include correspondence and personal papers documenting Hammer's remarkable career, from his early years in Moscow as a physician and representative of American businesses to a second career as a petrochemical entrepreneur, patron of the arts, and champion of cancer research. A special feature will be the numerous films, recordings, and other audiovisual material, some never before seen by historians, documenting Hammer's contacts with world leaders from Lenin to Reagan. The Library plans a special exhibit from the Hammer Collections on the occasion of his 90th birthday, May 21, 1988. During his lifetime and for an interval thereafter the papers may be consulted only with the permission of Hammer or those authorized to act on his behalf.

- North Carolina State University, Raleigh, has received a collection of 1,500 mystery novels covering the period 1920-1950. The volumes are the gift of professor emeritus Jack Levine, a mathematician and expert in cryptography.

- Simmons College, Boston, Massachusetts, has acquired the historical records of The Horn Book, the first magazine published with a concern entirely for children's books and reading. The records include correspondence, illustrations, manuscripts, photographs, scrapbooks and printed materials dating from 1916. The Horn Book was the creation of Bertha Mahoney Miller, a 1902 Simmons graduate who started a children's bookshop in Boston and eventually sent travelling exhibits of children's books around the region, developing a large mail-order business. Its correspondence files span generations of editors and include original letters from numerous authors including Beatrix Potter, Laura Ingalls Wilder, and Walter De La Mare.

-The University of North Carolina at Charlotte has received more than 3,900 volumes from the library of the late Alice Lindsay Tate of New York City as a memorial to her father, Robert Lindsay Tate. A descendant of a leading textile manufacturing family in Charlotte, Tate pursued an operatic career in various cities during the 1940s and '50s, and established several collections at UNCC. Included in the present gift are English language materials on Zen Buddhism, Chinese and Japanese literature, the religions of Asia (especially Tibet), and a number of books on Judaica and Hebraica. An additional 1,800 volumes on the occult, UFO phenomena, and archetypal symbols were directed to Johnson C. Smith University, also in Charlotte, in place of the now closed Boggs Academy, a Georgia high school. Additional photos and memorabilia of Tate's career were included, along with 15 paintings by Russian-born artist Nikolai Konstantinovich Roerich (1874-1947).

- The University of Rochester, New York, has acquired the complete papers of novelist, scholar and critic John Gardner (1933-1982). Filling 50 large storage boxes, the archive includes manuscripts and drafts of most of Gardner's works, including The Sunlight Dialogues, Grendel, Mickelsson's Ghosts, and On Moral Fiction, as well as family papers and correspondence with editors, other writers and admirers. The papers also include manuscripts for works not yet published as well as original paintings by Gardner, ephemera related to his teaching positions, and personal items like postcards, ticket stubs, grant applications, and letters from lawyers, accountants, hospi- 